\title{
Alcoholysis of Nyamplung Seed Oil Using Potassium Carbonate Gatalyst
}

\author{
Sofiyah \\ Department of Chemical Engineering \\ Gadjah Mada University, Yogyakarta, Indonesia \\ Email:sofiyah@chemeng.ugm.ac.id
}

\begin{abstract}
The production of glycerol and ester by alcoholysis of vegetable oils has been widely studied. Various catalysts, such as sodium and potassium hydroxide and sulfuric acid have been used to increase the rate of reaction. This preliminary research studied the possibility of using potassium carbonate catalyst. The experiment was conducted in an autoclave. A certain amount of nyamplung seed oil was poured into the autoclave and then the heater was switched on to heat up the oil to the required temperature of reaction. Besides, a mixture of ethanol and potassium carbonate was heated in a flask equipped with condenser to form ethanolate. As soon as the required temperature was reached, the ethanolate was quickly put into the autoclave containing the nyamplung seed oil. The temperature of the reaction was kept constant for a period of time. At the end of each process, a sample was withdrawn and analyzed for its glycerine content by acetin method. The variables studied were reaction time and catalyst concentration. The experimental data were evaluated by applying pseudohomogeneous approach. It was found that data were in good agreement with first order reaction with respect to nyamplung seed oil. Using an equivalent ratio of 5.1 ethanol to nyamplung seed oil, a temperature of $100^{\circ} \mathrm{C}$, and an agitation speed of $150 \mathrm{rpm}$, the favorable catalyst concentration was found to be at 0.008 gram of potassium carbonate per gram of nyamplung seed oil. Under this condition, the glyceride conversion was 0.5159 in $75 \mathrm{~min}$.
\end{abstract}

Keywords: Alcoholysis, autoclave, ester, nyamplung seed oil, and potassium carbonate.

\section{INTRODUCTION}

The nyamplung tree (Calophyllum inophyllum Linn.) grows throughout the Indonesian region. The tree grows to $20 \mathrm{~m}$ tall and produces big branches. The trees are commonly found on beaches and seashores but also sometimes inland (Senosastroamodjojo 1967).

The tree produces fruits, $3-4 \mathrm{~cm}$ in diameter. The fruit is green to yellow when it is ripe, and inside each fruit is one smooth spherical seed (nut) that is pale yellow. After a time (?), the seed turns brown and its oil content becomes very high. Nyamplung seed oil is extracted from these nuts by cold-pressing and filtration. The oil is dark green. Nyamplung seed oil contains an average of $14.7 \%$ palmitic acid (C16), $12.66 \%$ stearic acid (C18), $0.94 \%$ eicosanoic acid (C20), 49.4\% oleic acid (C18:1), 21.3\% linoleic acid (C18:2), $0.28 \%$ linonenic acid (C18:3), and $0.72 \%$ eocosenoic acid (C20:1). [www.aromatrading.co.uk]

Vegetable oils can be used directly as a fuel to substitute petroleum diesel but it may require certain engine modifications to avoid maintenance and performance problems (Puppung 1986). That is why, if it is used as fuel for conventional diesel engines, the oils must be 
further processed primarily because of its high viscosity. Biodiesel (fatty acid alkyl esters) is a renewable fuel that can be manufactured from new and used vegetable oils or animal fats. It is safe, biodegradable, and may reduce serious air pollution.

Alcoholysis (transesterification) of vegetable oils or animal fats, using alcohol in the presence of a catalyst, is the most popular process. Vegetable oils or animal fats are chemically reacted with an alcohol to produce chemical compounds known as fatty acid alkyl esters that, when used as fuel, are called biodiesel.

In addition, alcoholysis produces glycerol that is used extensively in pharmaceuticals and cosmetics. The equation reaction may be expressed as follows:

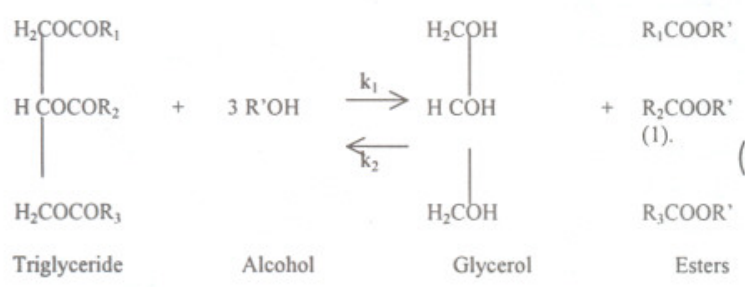

Alcoholysis is an equilibrium reaction; hence, to ensure the increase of triglyceride conversion, an excess of alcohol is used (Groggins 1958, Kirk and Othmer 1980). The rate of reaction is a function of temperature and catalyst concentration.

Various catalysts, such as sodium and potassium hydroxide, and sulfuric acid have been used to increase the rate of reaction (Agra et al. 1997, Freedman 1984, Kirk and Othmer 1980). The rate of alcoholysis using alkali catalyst is faster than using acid catalyst. At room temperature, the alkali-catalyzed reaction proceeeds rapidly, whereas acid-catalyzed reactions require temperatures above $100^{\circ} \mathrm{C}$ (Freedman et al. 1984).

In this preliminary research, potassium carbonate was used in the alcoholysis of nyamplung seed oil to increase the rate of reaction. Potassium carbonate was chosen because in the presence of water it can be hydrolyzed to form potassium hydroxide.

If potassium carbonate can increase glyceride conversion, then $\mathrm{K}_{2} \mathrm{CO}_{3}$ extracted from plant ash may substitute potassium carbonate. Two variables, reaction time and catalyst concentration, were studied. Experimental data were evaluated by applying pseudo. homogeneous approach.

\section{EXPERIMENTAL}

\section{Materials}

a. Nyamplung seed oil that contains $0.21 \%$ of water and with a saponification number 191;

b. Ethanol $86 \%$; and,

c. Potassium carbonate.

\section{Equipment}

The autoclave was equipped with a thermometer and a manometer, as well as with heating, rotating, and sampling devices.

\section{Procedure}

A required amount of nyamplung seed oil was poured into the autoclave and then the heater was switched on to heat up the oil to the required temperature of reaction. Meanwhile, a mixture of ethanol and potassium carbonate was heated in a flask equipped with condenser to form ethanolate.

As soon as the required temperature was reached, the ethanolate was quickly put into the autoclave. The solution's temperature in the autoclave was maintained constant for a period of time. At the end of each process, sample was withdrawn and analyzed for its glycerine content by acetin method (Griffin 1927). The variables studied were reaction time, from 15 to $90 \mathrm{~min}$, and catalyst concentration, from 0.4 to $0.9 \%$ by weight, of nyamplung seed oil.

\section{RESULTS AND DISCUSSIONS}

Preliminary experiment was performed to determine the ethanol concentration that is best suited for alcoholysis. The alcoholysis of nyamplung seed oil with and without catalyst were carried out at $100^{\circ} \mathrm{C}$, an equivalent ratio of ethanol $94 \%$ to nyamplung seed oil of $5: 1$, and a reaction time of $75 \mathrm{~min}$. The glyceride conversion 
achieved was $14.74 \%$ with catalyst and $13.29 \%$ without catalyst.

By using $94 \%$ ethanol, $\mathrm{K}_{2} \mathrm{CO}_{3}$ has little effect on glyceride conversion because the water content in ethanol was insufficient for the hydrolysis of $\mathrm{K}_{2} \mathrm{CO}_{3}$ to form $\mathrm{KOH}$. For this reason, a lower ethanol concentration of $86 \%$ was chosen.

\section{Effect of reaction time}

Table 1 and Figure 1 show that glyceride conversion increases with time. If $-\ln (1-x)$ is plotted against $t$, as shown in Figure 2, it gives a straight line. The line can be expressed as:

$$
-\ln (1-x)=0.0101 t-0.098
$$

where:

$$
\begin{aligned}
& x=\text { fractional conversion, and } \\
& t=\text { time, minute. }
\end{aligned}
$$

Table I. Effect of Reaction Time on Glyceride Conversion

\begin{tabular}{|c|c|}
\hline Time, min & Glyceride conversion, \% \\
\hline 15 & 9.19 \\
30 & 20.82 \\
45 & 20.62 \\
60 & 35.71 \\
75 & 55.98 \\
90 & 53.22 \\
\hline
\end{tabular}

The slope of the line indicates the value of the rate constant. Hence, the data is in good agreement with the pseudo first order reaction.

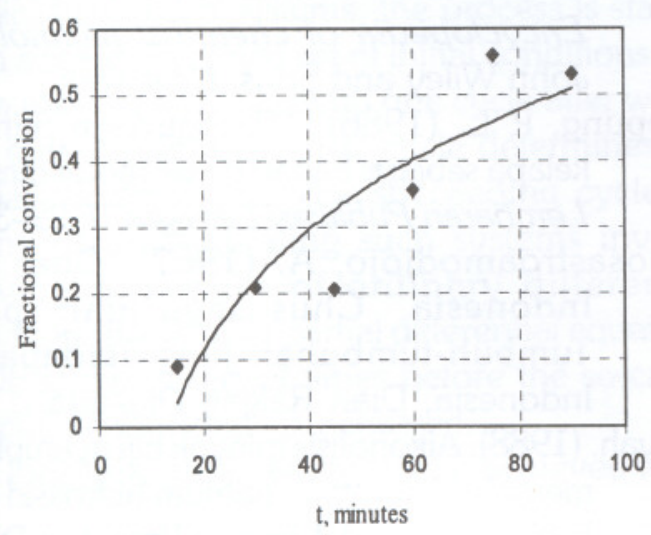

Figure 1. The Effect of Reaction Time on Glyceride Conversion
Table 2. Effect of Potassium Carbonate Catalyst on Glyceride Conversion

(Temperature $=100^{\circ} \mathrm{C}$, reaction time $=75$ minutes, equivalent ratio of ethanol to nyamplung seed oil $=5.1$ )

\begin{tabular}{|c|c|}
\hline $\begin{array}{c}\mathrm{K}_{2} \mathrm{CO}_{3} \\
\text { (\% by Weight of } \\
\text { Nyamplung Seed Oil) }\end{array}$ & $\begin{array}{c}\text { Glyceride Conversion } \\
(\%)\end{array}$ \\
\hline & \\
0.4 & 33.59 \\
0.5 & 40.39 \\
0.6 & 48.97 \\
0.8 & 51.59 \\
0.9 & 55.98 \\
\hline
\end{tabular}

\section{Effect of potassium carbonate catalyst}

In order to investigate the effect of catalyst concentration, the experiments were conducted at a constant temperature of $100^{\circ} \mathrm{C}$, an equivalent ratio of ethanol $86 \%$ to nyamplung seed oil of $5: 1$, and a reaction time (75 $\mathrm{min})$. The catalyst concentration studied ranged from 0.4 to $0.9 \%$ by weight of nyamplung seed oil.

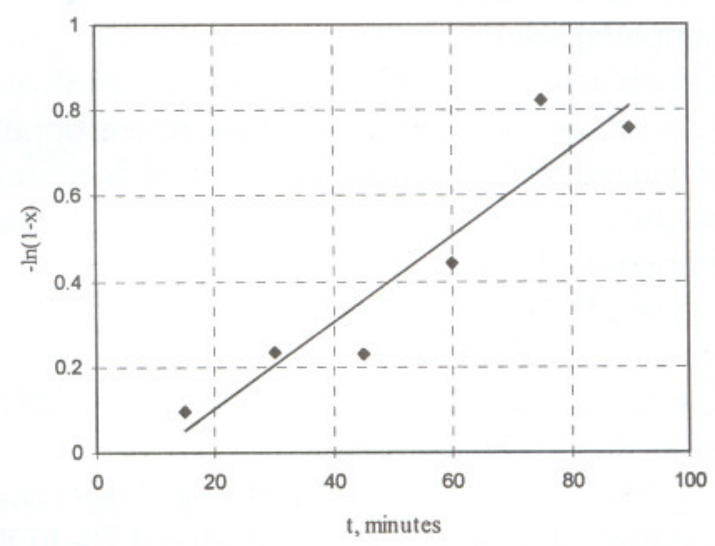

Figure 2. Check for Validity of Pseudo First Order Reaction Model

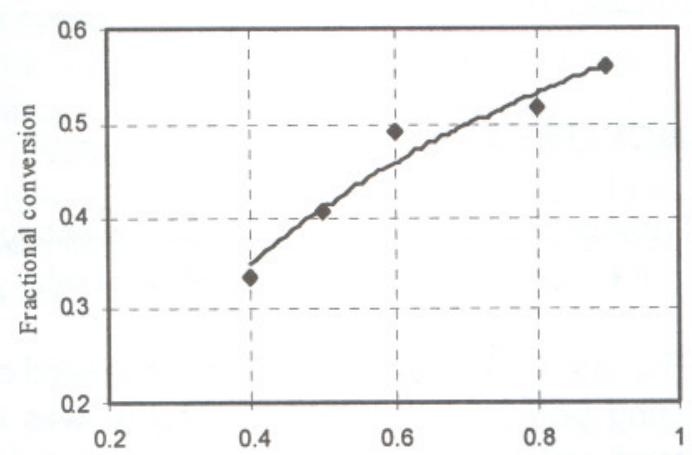

Catalyst concentration, \% by weight of nyamplung seed oil

Figure 3. The Effect of Catalyst Concentration on Glyceride Conversion 
Table 3. Comparison of Results with Those in Previous Work

\begin{tabular}{|c|c|c|c|c|}
\hline \multirow[b]{2}{*}{ Variable } & \multirow[b]{2}{*}{$\begin{array}{l}\text { Without } \\
\text { Any } \\
\text { Catalyst }\end{array}$} & \multicolumn{3}{|c|}{ Catalyst } \\
\hline & & $\begin{array}{l}\text { KOH } 0.7 \% \\
\text { by Weight } \\
\text { [Sofiyah } 1988 \text { ] }\end{array}$ & $\begin{array}{c}\mathrm{K}_{2} \mathrm{CO}_{3} 0.9 \% \\
\text { by Weight }\end{array}$ & $\begin{array}{c}\mathrm{K}_{2} \mathrm{CO}_{3} 0.8 \% \\
\text { by Weight }\end{array}$ \\
\hline Time, $\min$ & 75 & 60 & 75 & 75 \\
\hline Temperature, ${ }^{\circ} \mathrm{C}$ & 100 & 100 & 100 & 100 \\
\hline Equivalent ratio, & 5.1 & 5.1 & 5.1 & 5.1 \\
\hline mgeq/mgeq & 86 & 94 & 94 & 86 \\
\hline $\begin{array}{l}\text { Ethanol concentration, } \\
\% \text { fractional } \\
\text { conversion }\end{array}$ & 0.132 & 0.654 & 0.142 & 0.516 \\
\hline
\end{tabular}

Table 2 and Figure 3 show the effect of catalyst concentration on glyceride conversion. The glyceride conversion increases with catalyst concentration. This means that potassium carbonate can be used as catalyst for the alcoholysis of nyamplung seed oil.

\section{Comparison of results with those in previous work}

Table 3 shows the results of alcoholysis of nyamplung seed oil with and without catalyst. The catalysts used were $\mathrm{KOH}$ (Sofiyah 1988) and $\mathrm{K}_{2} \mathrm{CO}_{3}$. It can be seen that potassium carbonate has little effect on the conversion if $94 \%$ ethanol was used. This was because of the insufficient water content in ethanol.

If $86 \%$ ethanol was used, the glyceride conversion increased from 0.132 to 0.516 , because the water content in $86 \%$ ethanol is higher than in $94 \%$ ethanol.

Table 3 also shows that the fractional conversion of triglyceride catalyzed by $0.7 \% \mathrm{KOH}$ and $0.8 \% \mathrm{~K}_{2} \mathrm{CO}_{3}$ are 0.654 and 0.5216 , respectively. This is because $\mathrm{K}_{2} \mathrm{CO}_{3}$ cannot be hydrolyzed completely.

\section{CONCLUSIONS}

1. Potassium carbonate can be used as catalyst in the alcoholysis of nyamplung seed oil.

2. The rate of alcoholysis of nyamplung seed oil using potassium carbonate catalyst was in good agreement with the pseudo first order reaction with respect to nyamplung seed oil.

\section{ACKNOWLEDGMENTS}

The author expresses her appreciation for the financial aid given by the Faculty of Engineering of Gadjah Mada University. The author also gratefully acknowledges Prof. Dr. Ida Bagus agra and Prof. I Made Bendiyasa, Ph.D., for their support of this research.

\section{REFERENCES}

Agra, I. B.,Warnijati, S., and Junaedi, P. (1997). "Ethanolysis of Jatropha curcas oil at higher pressure using sodium hydroxide as catalyst," Proceedings of the Second ASEAN Renewable Energy Conference, Phuket.

Freedman, B., Pryde, E. H., and Mount, T. L. (1984). "Variables affecting the yields of fatty ester from transesterified vegetable oils," JAOCS, 61, 1638-1642.

Griffin, R. C. (1927). Technical methods of analysis, McGraw-Hill Book Co., Inc., New York.

Groggins, P. H. (1958). Unit processes in organic synthesis, McGraw-Hill, New York.

Kirk, R. E., and Othmer, D. F. (1980). Encyclopedia of chemical technology, John Wiley and Sons, New York.

Puppung, P. L. (1986). "Penggunaan minyak kelapa sebagai bahan bakar motor diesel," Lembaran Publikàsi Lemigas, 1, 29-35.

Senosastroamodjojo, A. (1967). Obat Asli Indonesia, Chususnya dari pada Tumbuh-tumbuhan jang Terdapat di Indonesia, Dian Rakjat, Djakarta.

Sofiyah. (1988). Alkoholisis minyak biji nyamplung memakai katalisator natrium hidroksid dan kalium hidroksid, Laporan Penelitian DPPSPP, Fakultas Teknik UGM, Yogyakarta. www.aromatrading.co.uk 